\title{
A Study on the Mobile Learning of English and American Literature Based on Wechat Public Account
}

\author{
Guiyu Dai ${ }^{1}$, Yang $\mathrm{Liu}^{2} \&$ Shanmeng $\mathrm{Cui}^{2}$ \\ ${ }^{1}$ Center for Foreign Literature and Culture, School of English for International Business Studies at Guangdong \\ University of Foreign Studies, Guangzhou, China \\ ${ }^{2}$ Faculty of English Language and Culture at Guangdong University of Foreign Studies, Guangzhou, China \\ Correspondence: Yang Liu, Faculty of English Language and Culture at Guangdong University of Foreign Studies, \\ Guangzhou, China. Tel: 86-155-2106-0623. E-mail: 273036939@qq.com
}

Received: April 12, 2018 Accepted: May 10, 2018 Online Published: May 12, 2018

doi: 10.5539/elt.v11n6p47 URL: http://doi.org/10.5539/elt.v11n6p47

\begin{abstract}
This paper uses Edgar Dale's Audio-visual Learning Theory and Jean Piaget's Constructionist Learning Theory as the theoretical framework to conduct two control experimental tests and a questionnaire research to investigate students' impression and expectations toward Wechat public account based mobile learning mode as well as its validity, advantages and shortcomings. The findings of the research are as follows: (1) students who use the WeChat public account based mobile learning mode can perform better in acquiring knowledge and passing examinations than non-users; (2) students' mobile learning habits find a good basis for their acceptance of the new WeChat learning mode; (3) most students respond to the new WeChat learning mode with a positive attitude, and universities can introduce this mode into the course design; (4) this new WeChat learning mode helps students learn literature in the aspects of interest stimulation, ability improvement and literature content learning; (5) WeChat mobile learning is only an extension of the current form of learning and cannot replace the current traditional school education; (6) Mobile learning mode based WeChat public account is an important teaching aid for teachers in the aspects of information dissemination, interactive mode and updated contents; (7) The experience of improving the current mobile learning model of WeChat public account can be enriched from students' feedback. It is hoped that WeChat mobile learning will efficiently activate students' learning potentials and promote English and American literature teaching innovation.
\end{abstract}

Keywords: control experiment, empirical study, Wechat mobile learning, Wechat public account, mobile learning mode

\section{Introduction}

The English and American Literature course offered by universities and colleges for English majors in China is a compulsory course which aims to improve students' literary appreciation and English competence, open their multidimensional perspectives in dialectical thinking and logical analysis and promote their humanistic quality. However, with the development of market economy and the prevalence of educational pragmatism in recent years, people are getting more and more practical and paying less attention to liberal arts courses. As a result, the English and American literature curriculum is gradually being marginalized. How to make traditional subjects play their new role in current age? How to improve students' interest in studying literature? How to change the outdated students' literature learning mode and how to enrich students' amateur literature learning activities? These are the questions constantly considered by literature teachers in colleges and universities.

With the advent of the information and big data age, a new teaching mode - the mobile learning model has come into being. Mobile Internet learning, also known as mobile learning (M-learning), mainly refers to the use of wireless communications technology and Internet technology and mobile devices to learn in anytime anywhere. As mobile learning has the following characteristics: flexibility, convenience, and mobility, it is highly welcomed among university students. Wechat public accounts, one type of mobile learning mode, are specially and widely subscribed by university students.

This paper tries to create Wechat public account based mobile learning mode by combining Wechat public account with arranged content of English and American literature. To evaluate this mode, this paper makes two 
control experiments and a questionnaire to test the effectivity of Wechat public account based literature mobile learning.

\section{Literature Review}

In recent 5 years, Wechat platform teaching evolves a novel trend in China. Many scholars have applied this innovative teaching method to their course design. Tian and Wei (2014) utilize the hybrid cloud model of mobile learning environment to design and implement Arabic course learning based Wechat public platform and analyze the results of hybrid cloud model of mobile learning. Xu et al. (2015) fully exploit the educational affordances of WeChat Media Platform, and construct a new blended learning model aiming at addressing the above-mentioned problems of traditional teaching. Shan et al. (2015) present a case study of the "Data Structure" (DS) course which is based on the WeChat public platform to discover the learning model of micro-learning. From the perspective of interactive language theory, Liu and Jiang (2015) analyze the advantages of applying Wechat to the College English Teaching, and design an innovative Wechat platform of the College English Teaching on the basis of modern network and mobile technology. Jiang et al. (2016) construct a Wechat-based learning model of multi-terminal interactive inquiry, and analyze the feasibility of the model from the dimensions of pedagogy, social interaction and technological support. Miao (2016) discusses the feasibility of WeChat software application in English mobile learning in universities and colleges as well as the design paradigms and application modes and offers Wechat based English mobile learning strategies from multiple levels in practice. Wang et al. (2016) compare distance education platform with Wechat public platform through analyzing the structure and content of the two network platforms of distance learning and propose that the suitable presentation form of WeChat public platform should be selected and the corresponding module according to the curriculum requirements would be designed, so as to achieve the complementary advantages of these two platform resources. Ye (2017) takes Foreign Literature course at Sichuan University as a case to analyze the application of the Internet and finds that this kind of course platforms can raise teaching efficiency. Based on the PST theories and its related achievements, Meng (2017) starts from the theoretical research on the recessive classroom construction of Foreign Literature in colleges and universities based on WeChat platform to expand the students' learning time and space and further improve the quality of foreign literature teaching.

Based on the previous researches, this study has borrowed their successful experience on how to design, organize, and edit an influential and effective Wechat public platform. This study has selected necessary learning materials, important literature background information to fill in valuable corresponding modules in the Wechat platform according to the syllabus of this semester. Rather than use English as a single language tool to transmit significant course knowledge to students, this study has also innovatively adopted Chinese as a supplementary language tool to show a summary of the literary figure presented on a certain week. According to the course syllabus, our Wechat program consists of 12 weeks' articles as supplementary learning materials to enlarge students' knowledge of course contents. Varied chunks representing different knowledge module form the major structure of each week's article. Verbal, audio and visual information is all employed in all 12 weeks' articles. Each week's article is comprised of several parts including lead-in, keywords explanation and translation, writers' or poets' information, extended readings and comments on each week's theme.

\section{Theory background}

Our GDUFS Wechat literature study program is mainly founded on two researchers' theories: the audio-visual learning theory by Edgar Dale and the constructionist learning theory by Jean Piaget.

\subsection{Edgar Dale's Audio-Visual Learning Theory}

Edgar Dale constructs a learning pyramid (in Figure 1), which is widely cited in different learning subjects and fields such as problem-based learning (Northwood et al., 2003; Wood, 2004; Woods, 2006; Yeh et al., 2011), computer-based training and simulation (Barnes 2001; Buehler et al. 2001; Chen et al. 2007; Krain \& Lantis 2006) case-based learning (Golich et al., 2000) and other constructivist activities (Harker 2008; Khan et al. 2012; Pinto et al., 2012) as well as general education (Martinez \& Jagannathan, 2010; Pinto et al., 2012). 


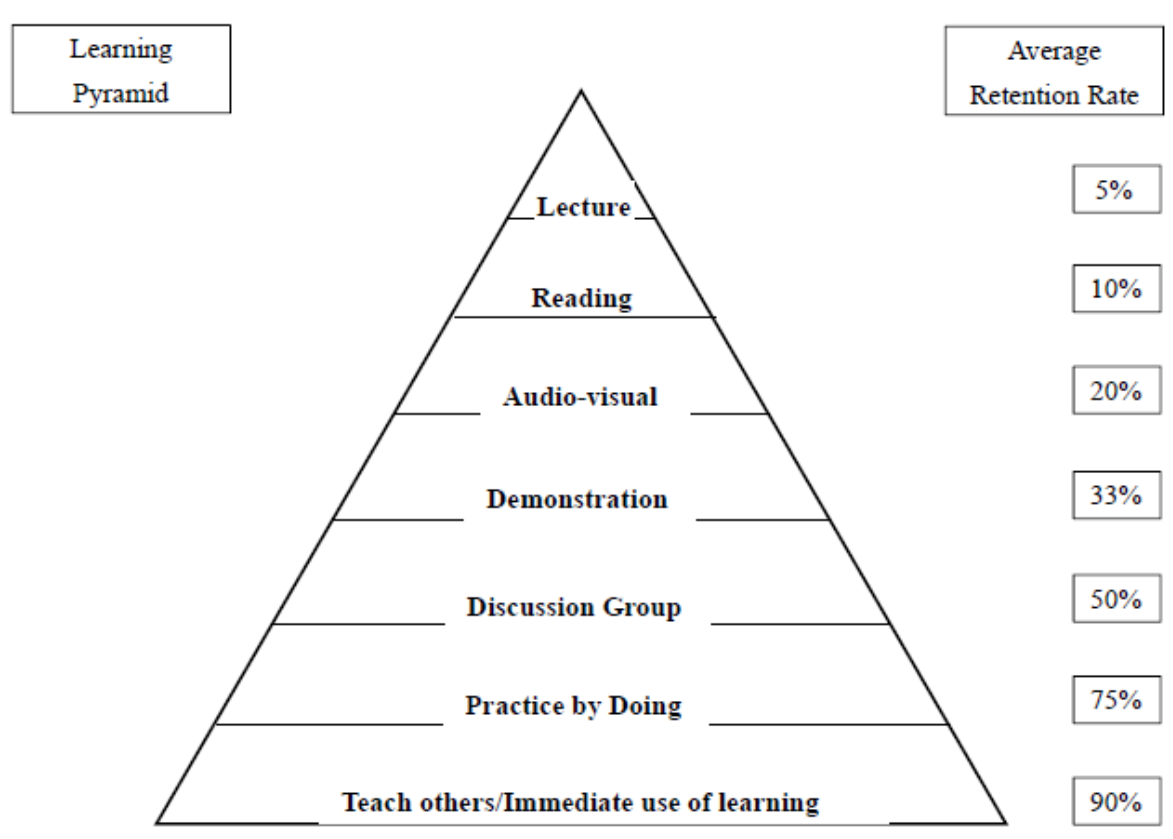

Figure 1. The NTL Learning Pyramid, "sometimes with slightly different percentages, appears as [this figure]"

(Ken Mastersab, 2013)

Edgar Dale (1970) stresses the efficiency and explains the reasons of using audio-visual materials in learning process. He points out that audio-visual-verbal materials can function as more concrete experiences, which "are nearly always skillfully integrated with words themselves". Students can be helped to move toward a greater degree of workable, clear and useful symbolization as well as generalization when they abstract and generalize from videoed experiences at varying levels of complexity. Pictures can present what cannot be easily or satisfactorily described by words and help students learn how to draw off and test inferences by emphasizing process not product.

Cooper's (1958) theory of efficiency also can be explained by Edgar Dale's audio-visual learning theories' analysis of the mechanism that explains how people forget learned materials. Cooper points out that people's efficiency with any new medium or technique has four stages, including unconscious inefficiency when people perform badly but don't know it; conscious inefficiency when people know they could do better but don't know what to do to improve; conscious efficiency when people are applying new methods with painful proficiency; and unconscious efficiency when people have learned how to use the new method "without thinking".

Reasons are stated clearly by Edgar Dale (1970), who believes that audio-visual methods of instruction can reduce forgetting and make learning more permanent. Pictures can enhance the understandability, significance and usability frequency of materials students need to learn. With concrete pictures, students can be helped to see what might otherwise remain abstract. Pictures make events seem more real and therefore more important, they relate the things studied in the class room to real experiences of real people in daily life, tying up the old to the new, the known to the unknown.

\subsection{Jean Piaget's Constructionist Learning Theory}

Similar to Edgar Dale's audio-visual learning theory, constructivist learning theory also believes the power of understanding and experiencing in stimulating learners' senses, which are presented by Jean Piaget (Harel \& Papert, 1991). Jean Piaget's role in the constructivist teaching suggests that people learn by expanding their knowledge and experiences which are generated through play from infancy to adulthood which are necessary for learning (Harel \& Papert, 1991). In this approach, the individual is consciously engaged in the construction of a product ( $\mathrm{Li}$ et al., 2013). The utilization of constructionism in educational settings has been shown to promote higher-order thinking skills such as problem-solving and critical thinking (Li et al., 2013). Constructivism thinks that children are not a blank slate and knowledge cannot be imparted without the child making sense of it according to his or her current conceptions. Therefore, children learn best when they are allowed to construct a personal understanding based on experiencing things and reflecting on those experiences. 
One of the primary goals of using constructivist teaching is that students learn how to take initiative for their own learning experiences. A constructivist classroom demonstrates the following characteristics: actively involved-learners; democratic environment; interactive and student-centered activities; a learning process facilitating students to be responsible and autonomous (Schmidt \& Loyens, 2007). Contrary to the traditional classroom in which students work primarily alone, learning is achieved through repetition, and the subjects are strictly adhered to and are guided by a textbook. Constructivism activities encourage learning methods such as experimentation where students individually perform an experiment and then come together as a class to discuss the results; research projects where students research a topic and can present their findings to the class; field trips where students are allowed to put the concepts and ideas discussed in class in a real-world context; films where these provide visual context and thus bring another sense into the learning experience; class discussions where this technique is used in all of the methods described above. By working primarily in groups, a constructivist classroom can foster interactive and dynamic learning process. There is a great focus and emphasis on social and communication skills, as well as collaboration and exchange of ideas (Schmidt \& Loyens, 2007).

Constructivist approaches can also be used in Wechat program learning as in this GDUFS literature education program. Wechat learning program can function as discussion forums, wikis and blogs, enabling learners to actively construct knowledge.

Some other researchers in education share their opinions in educational theories, which can help fill in the loopholes of constructivism theories' disadvantages. Mayer (2004) developed a literature review spanning fifty years and concluded the formula constructivism is a formula for educational disaster, functioning just like hands-on activity. His argument is that in developing educators produce materials that require learning to be behaviorally active and not be "cognitively active". It means that activity is not surely direct students to real learning, and students may be just doing activities but forget learning (Sweller, 1988). Mayer suggests combining direct instruction and hands-on activity, rather than pure discovery: "In many ways, guided discovery appears to offer the best method for promoting constructivist learning."

Kirchner et al. (2006) holds the opinion that "the constructivist description of learning is accurate, but the instructional consequences suggested by constructivists do not necessarily follow." They doubt the accurateness of instructors' design and fear unguided instruction can bring learners to aimless achievement because learners need to "discover or construct essential information for themselves" (Kirchner et al., 2006). Therefore, they agree with Mayer's (2004) recommendation that educators need to shift from too much emphasis on the nonproductive ideology to the real constructivism that can establish a sharp and productive mechanism to dig out how people learn.

\section{The Process of the Empirical Study}

\subsection{Creating a Wechat Public Account Based Mobile Leaning Mode}

We use Wechat public account as a platform and create a public account for appreciation of English and American literature. We mainly provide verbal, audio and visual information about one important English or American writer and his/her works on Wechat public account every week. The whole experiment contains 12 articles and each article consists of five parts, namely, lead-in, keywords explanation and translation, writers' or poets' information, extended readings and comments on each week's theme. Most of the content is written in English except for some titles, translations and UI default design language. In the lead-in part, we provide a reading audio or a short film clip to arouse students' interest in learning English and American literature. Then we offer the keywords and translation of previous lead-in part. In the third part, it is necessary to note the writers' or poets' life and experience as well as the literary period of the writer. In the following part, we recommend one or two works of one writer and some other famous writers in the same period and make a comparison between them. At last, we give a brief comment on the writer and the work chosen in this article. The interface of the Wechat public account and one example of its articles are listed in Figure 2 below: 


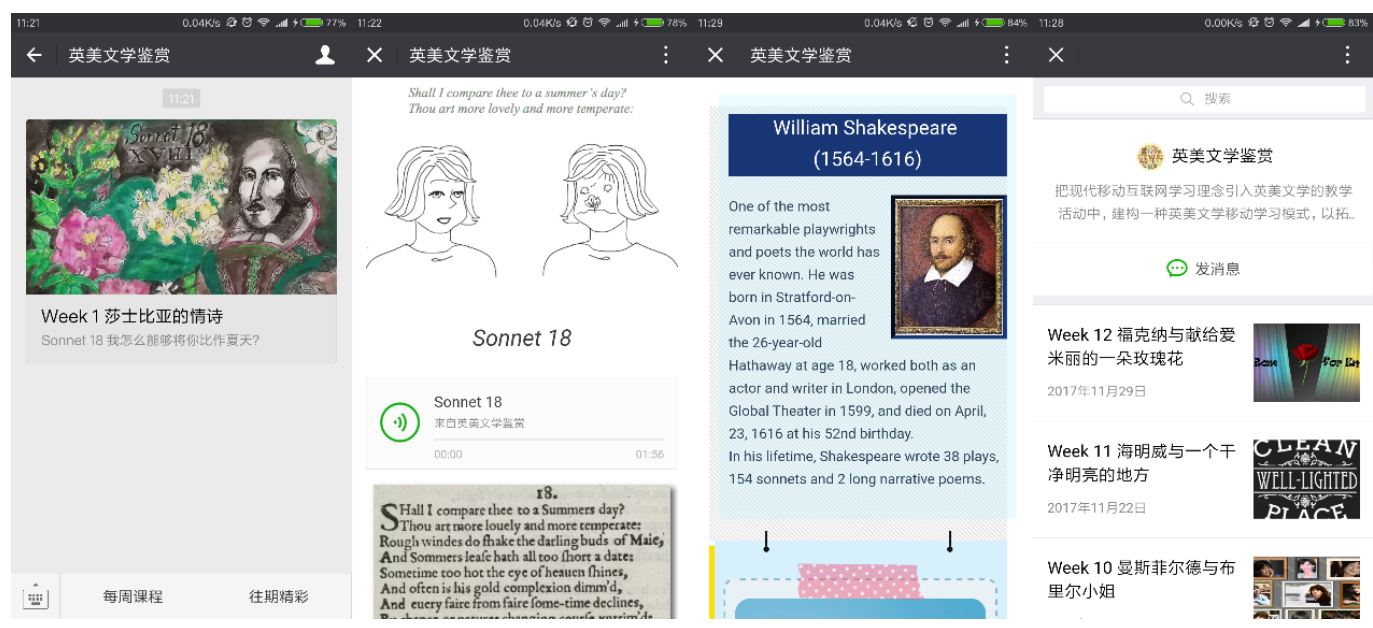

Figure 2. The interface of Wechat public account

\subsection{Control Experiment Design}

In this study, we make two control experiments to evaluate the efficiency of the Wechat public account based mobile learning mode. These two experiments conducted in the second semester of 2017-2018 academic year of Guangdong University of Foreign Studies randomly chose 97 undergraduate junior students in International Business English Program. 97 students are randomly divided into two groups (experiment group, 49 people; control group, 48 people). Students of the experiment group are using Wechat public account to get English and American literature information in a way to assist and complement teacher's classroom teaching. Meanwhile, the control group uses the traditional classroom teaching without Wechat mobile learning mode. Students from experiment group uses Wechat platform to get literary resources ahead of each week's literature class. In advance to the two experiments, a pretest is used to meet the basic requirements of control experiments. Two control experiments are the mid-term test and final test. The results are analyzed through SPSS software to test the Independent Samples Test between control group and experiment group.

\subsection{Pretest for the Control Experiments}

In order to know if students' literature knowledge is at the same level before participating formal experiments, all 97 students are (experiment group, 49; control group, 48) required to take the pretest including 10 basic multiple choice questions of English and American literature at the beginning of their first literature class. 10 for each and full mark is 100 . The results are analyzed by SPSS 22 statistics software, which are listed in Table 1 and Table 2. Group 1 stands for control group while group 2 is the experiment group. From the result of Table 1 (Independent Sample T-Test of the pretest), we can clearly see the experiment group's mean is 41.84 and the control group is 39.38. In Table 2, the 2-tailed significance of the equal variances assumed is 0.373 which is more than 0.05 (the Confidence Interval is $95 \%$ ), so that it indicates there is no significant difference in the pretest of two groups of students. In other words, all the students from control group and experiment group perform the same ahead of literature knowledge learning and are available for the next stage of experiment.

Table 1. Group statistics

\begin{tabular}{llllll}
\hline & group & $\mathrm{N}$ & Mean & Std. Deviation & Std. Error Mean \\
\hline score & 1 & 48 & 39.38 & 12.275 & 1.772 \\
\cline { 2 - 5 } & 2 & 49 & 41.84 & 14.673 & 2.096 \\
\hline
\end{tabular}


Table 2. Independent samples test

\begin{tabular}{|c|c|c|c|c|c|c|c|c|c|c|}
\hline & & $\begin{array}{l}\text { Leven } \\
\text { for } \quad \\
\text { of Vari }\end{array}$ & $\begin{array}{l}\text { Test } \\
\text { uality } \\
\text { ces }\end{array}$ & t-test & or Equali & $y$ of Means & & & & \\
\hline & & & & & & Sig. & Mean & Std. Error & $\begin{array}{l}95 \% \mathrm{C} \\
\text { Interval } \\
\text { Differe }\end{array}$ & $\begin{array}{l}\text { of the } \\
\text { ofidence }\end{array}$ \\
\hline & & $\mathrm{F}$ & Sig. & $\mathrm{t}$ & $\mathrm{df}$ & (2-tailed) & Difference & Difference & Lower & Upper \\
\hline score & $\begin{array}{l}\text { Equal } \\
\text { variances } \\
\text { assumed }\end{array}$ & 4.102 & .046 & -.895 & 95 & .373 & -2.462 & 2.750 & -7.920 & 2.997 \\
\hline & $\begin{array}{l}\text { Equal } \\
\text { variances } \\
\text { not } \\
\text { assumed }\end{array}$ & & & -.897 & 92.740 & .372 & -2.462 & 2.745 & -7.912 & 2.989 \\
\hline
\end{tabular}

\subsection{Questionnaire Design}

The questionnaire that can be seen in the Appendix investigates respondents of all the 49 students from the experiment group. Among all the respondents, 6 are male and 43 are female, the latter accounting for $87.76 \%$. All the respondents are in their adolescence of junior university undergraduate students. The questionnaire contains two kinds of questions, namely, Likert-5 scale ( $1=$ "strongly disagree", $5=$ "strongly agree") multiple-choice questions and multiple-choice questions (more than one answer). The questionnaire is released after those students finish the previous two control experiments.

The questionnaire consists of five parts. The first part is about the students' basic information; the second part is students' impression of Wechat public account based mobile learning mode; the third part is about the validity of Wechat public account based mobile learning mode. In Part four, we make a comparison between Wechat public account based mobile learning mode and teacher classroom teaching. Part five consists of several questions about expectations of Wechat public account based mobile learning mode. Part 1 mainly includes gender information and their previous experience of Wechat platform as well as the time spent in using mobile learning. Part 2 includes students' attitude towards Wechat public account based mobile learning and some related questions. Part 3 deals with the Wechat platform learning's attraction to students, teacher's teaching and students' ability cultivation. Part 4 focuses on the relationship between traditional teaching and mobile learning. Part 5 investigates the students' feedback towards current Wechat public account based mobile learning mode.

\section{Results and Discussion}

\subsection{Results of Two Control Experiments}

After the first phase of two control experiments, we get the results listed in the following Table 3 and Table 4 . From the statistics of mid-term test, we can see there are some different aspects. First difference exists in the mean of students' scores. Experiment group's mean is 83.27, higher than the control group's mean (73.75), which is shown in Table 3.

Table 3. Group statistics

\begin{tabular}{llllll}
\hline & group & $\mathrm{N}$ & Mean & Std. Deviation & Std. Error Mean \\
\hline score & 1 & 48 & 73.75 & 14.198 & 2.049 \\
& 2 & 49 & 83.27 & 15.054 & 2.151 \\
\hline
\end{tabular}

Secondly, Table 4, the independent sample test of mid-term result, shows that the 2-tailed significance in t-test for Equality of Means is 0.002 which is much lower than the assumed 0.05 (95\% Confidence Interval), which means that the means between two groups are significant in numerical value. So the experiment group gets higher score than the control group and we can believe that the Wechat public account mobile learning mode achieves its success in the first phase of the control experiment. 
Table 4. Independent samples test

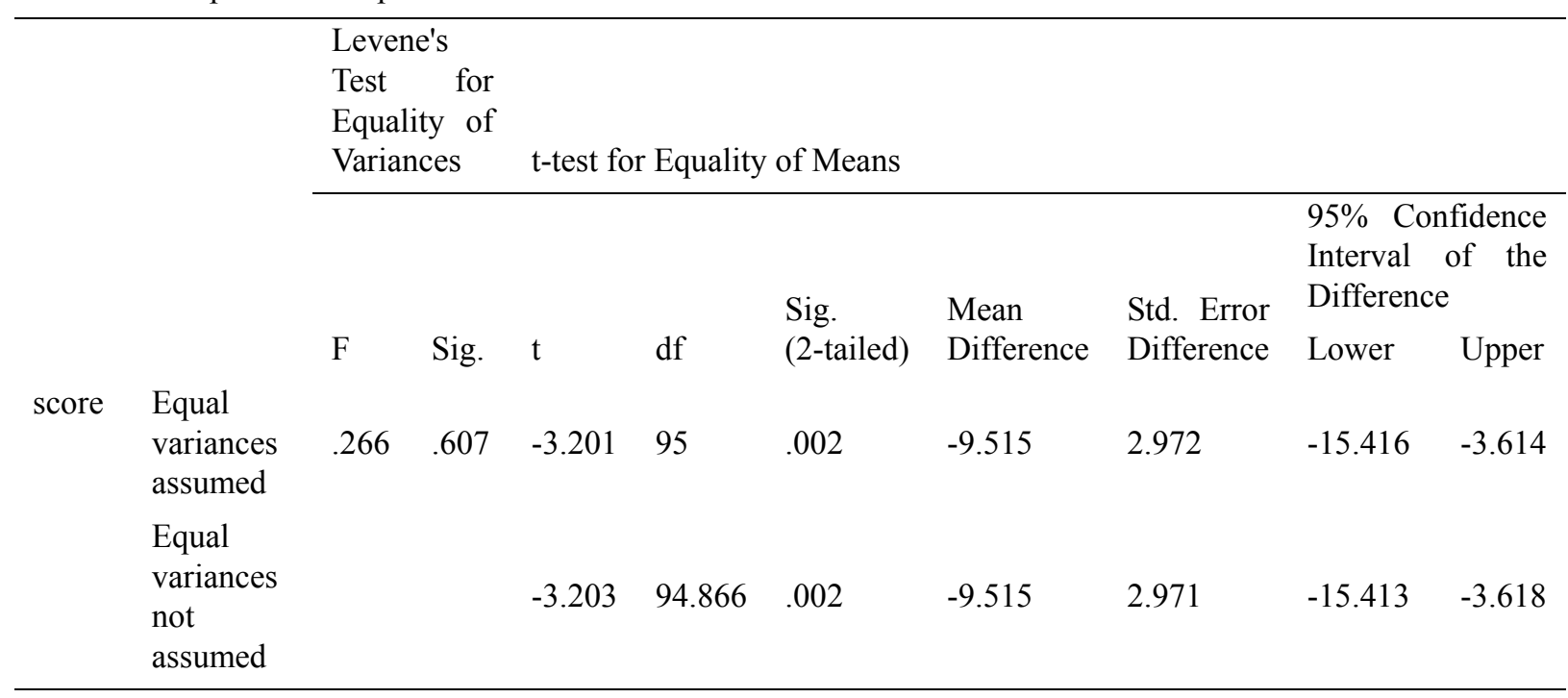

The result (Table 5) of the second phase of the control experiment indicates that students from experiment group scores higher than the control group as the mean of group 2 (91.112) is higher than the mean of control group (88.167).

Table 5. Group statistics

\begin{tabular}{llllll}
\hline & group & $\mathrm{N}$ & Mean & Std. Deviation & Std. Error Mean \\
\hline score & 1 & 48 & 88.167 & 8.1621 & 1.1781 \\
& 2 & 49 & 91.112 & 5.6654 & .8093 \\
\hline
\end{tabular}

Table 6. Independent samples test

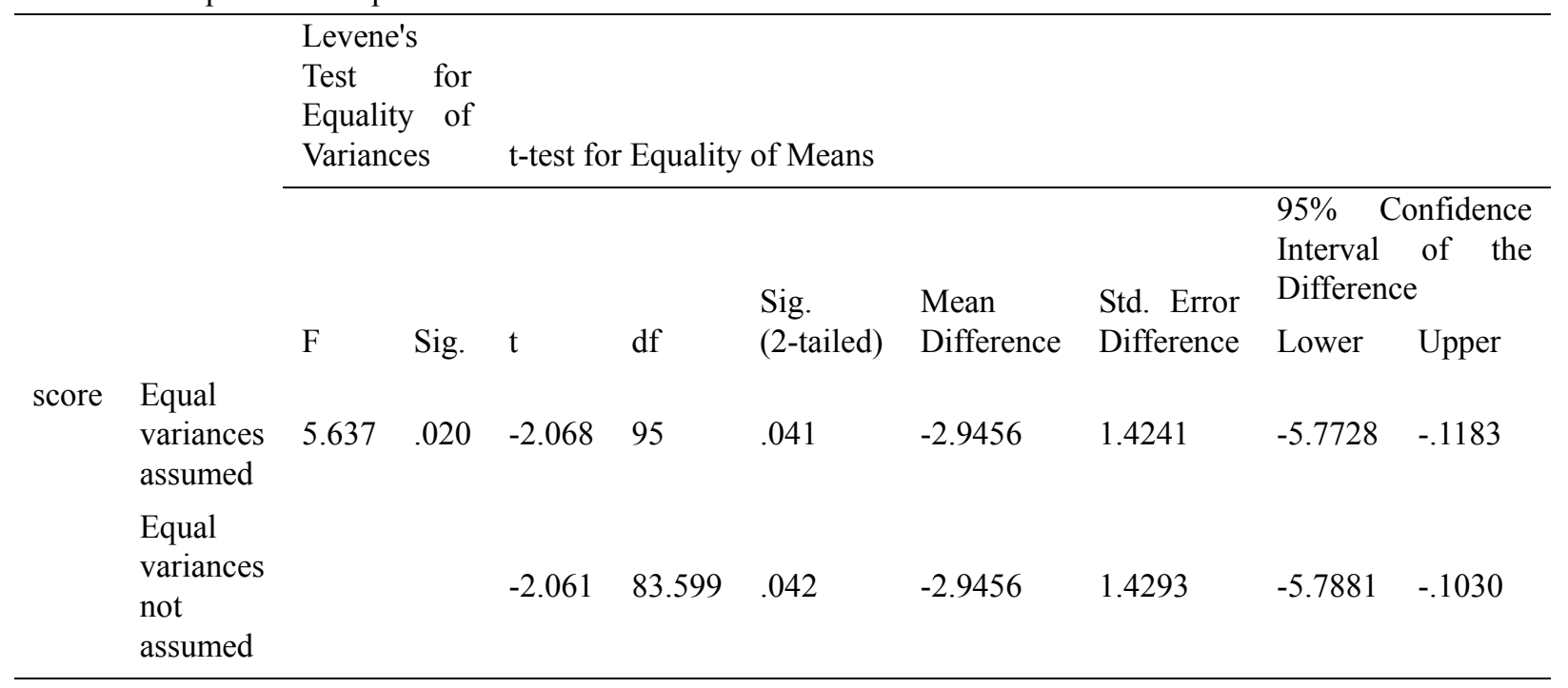

The 2-tailed significance of the t-test for Equality of Means is 0.041 , less than 0.05 (95\% Confidence Interval), which shows in the Table 6. It once again confirms the difference between the control group and the experiment group after using Wechat as a supplementary teaching method. Students perform better with the help of Wechat public account based mobile learning mode. 


\subsection{Result of the Questionnaire}

49 questionnaires are issued and 49 are valid. From part 1, the basic information about students can be seen from Question 1, 2 and 3. Percentage of female students is much larger than male students, which are $87.76 \%$ and $12.24 \%$ respectively. As for the students' experience on Wechat platform learning, $83.67 \%$ of students choose YES in Question 2 (Have you ever used mobile learning resources on Wechat platform?), which indicates the trend of mobile learning potential among university students. The result of Question 3 (Table 7) shows that $71.43 \%$ of students spend less than 1 hour in one day on mobile learning, while only 9 students accounting for $18.37 \%$ prefer to spend $1-2$ hours on mobile learning. Students who choose more than 2 hours' mobile learning take the lowest percentage (10.2\%) among three options. Thus, we know most of the students used to learning with the help of mobile platform such as Wechat or Weibo, which can be a good foundation to introduce the present Wechat public account based mobile learning mode.

Table 7. Q3: How many hours do you spend on mobile learning every day

\begin{tabular}{lll}
\hline Options & Number & Percentage \\
\hline Less than 1 hour & 35 & 71.43 \\
$1 \sim 2$ hours & 9 & 18.37 \\
More than 2 hours & 5 & 10.2 \\
\hline
\end{tabular}

Part 2 contains 3 Likert scale questions about the students' impression towards Wechat public account based mobile learning mode after finishing the control experimental test. In terms of familiarity, most of the students (65.31\%) choose neutral when they respond to Question 4 (I know Wechat public account based mobile learning mode) as listed in Table 8 .

Table 8. Q4: I know Wechat public account based mobile learning mode

\begin{tabular}{lll}
\hline Options & Number & Percentage \\
\hline Strongly disagree & 3 & 6.12 \\
Disagree & 8 & 16.33 \\
Neutral & 32 & 65.31 \\
Agree & 4 & 8.16 \\
Strongly agree & 2 & 4.08 \\
\hline
\end{tabular}

Students who choose the option of "strongly disagree", "disagree", "agree" and "strongly agree" account for $6.12 \%, 16.33 \%, 8.16 \%$ and $4.08 \%$ respectively and none of them over $50 \%$. The mean of Q4 Likert scale is 2.88 , which indicates that although students use Wechat platform as a new channel to learn English and American literature but they cannot give a clear definition or tell the exact difference between other kinds of mobile learning such as Weibo and Internet.

Question 5 investigated whether students like the Wechat public account mobile learning mode or not, the results are showed in Table 9.

Table 9. Q5: I like Wechat public account based mobile learning mode

\begin{tabular}{lll}
\hline Options & Number & Percentage \\
\hline Strongly disagree & 1 & 2.04 \\
Disagree & 3 & 6.12 \\
Neutral & 15 & 30.61 \\
Agree & 29 & 59.18 \\
Strongly agree & 1 & 2.04 \\
\hline
\end{tabular}


Table 9 tells us that most students like this mobile learning mode for $59.18 \%$ of students choose "agree" to this question while only several of them strongly disagree or disagree with Question 5. The mean of Question 5 is 3.53 which is in the positive range of 3.5-5.0, so once again it proves the students' interests in Wechat public account based mobile learning mode.

Question 6 is about students' subjective perceptions of adaption to Wechat public account based mobile learning mode. The statistics in Table 10 reflects that most of the students can adapt to Wechat public account based mobile learning mode on the whole because the mean of Question 6 is 3.51 which is higher than 3.5. Looking into the detail information, we find that $48.98 \%$ of the students agree with the statement in Question 6 and $28.57 \%$ of them stay neutral in their stand to this question.

Table 10. Q6: I can adapt to Wechat public account based mobile learning mode

\begin{tabular}{lll}
\hline Options & Number & Percentage \\
\hline Strongly disagree & 3 & 6.12 \\
Disagree & 3 & 6.12 \\
Neutral & 14 & 28.57 \\
Agree & 24 & 48.98 \\
Strongly agree & 5 & 10.2 \\
\hline
\end{tabular}

Part 3 mainly deals with the validity of current Wechat public account based mobile learning mode. This part includes 8 Likert scale multiple choice questions. According to the result analysis of the Question 7 (Table 11), it is certain to say that Wechat public account based mobile learning mode do arouse students' interest in learning English and American literature. 59.18\% of the students agree with this statement and the mean of Question 7 (3.55) lies in a positive range of the statement.

Table 11. Q7: The Wechat public account based mobile learning mode arouses my interest in learning English and American literature

\begin{tabular}{lll}
\hline Options & Number & Percentage \\
\hline Strongly disagree & 1 & 2.04 \\
Disagree & 8 & 16.33 \\
Neutral & 7 & 14.29 \\
Agree & 29 & 59.18 \\
Strongly agree & 4 & 8.16 \\
\hline
\end{tabular}

Question 8 is about validity of mobile learning mode in promote students' skills.

Table 12. Q8: I think Wechat public account based mobile learning mode can improve the self-learning ability of English and American literature

\begin{tabular}{lll}
\hline Options & Number & Percentage \\
\hline Strongly disagree & 1 & 2.04 \\
Disagree & 4 & 8.16 \\
Neutral & 6 & 12.24 \\
Agree & 33 & 67.35 \\
Strongly agree & 5 & 10.2 \\
\hline
\end{tabular}

From Table 12, we can see that over two thirds of students feel Wechat public account based mobile learning 
mode can improve the self-learning ability of English and American literature. The mean of Question 8 is 3.76 which is quite certain in the performance of Wechat public account based mobile learning mode.

Table 13. Q9: I think Wechat public account based mobile learning mode can help teachers better teach English and American literature courses

\begin{tabular}{lll}
\hline Options & Number & Percentage \\
\hline Strongly disagree & 1 & 2.04 \\
Disagree & 3 & 6.12 \\
Neutral & 8 & 16.33 \\
Agree & 29 & 59.18 \\
Strongly agree & 8 & 16.33 \\
\hline
\end{tabular}

As for this mode's supplementary function to teachers' traditional classroom teaching, the data of Table 13 shows that $59.18 \%$ of the students believe Wechat public account based mobile learning mode can help teachers better teach English and American literature courses. The percentages of strongly agree and neutral are the same which are both $16.33 \%$ and few of students choose the options of strongly disagree $(2.04 \%)$ and disagree $(6.12 \%)$. The mean (3.82) also reflects the positive side of Question 9.

Question 10 considers the side effect caused by Wechat public account based mobile learning mode and the result is listed in Table 14 as below.

Table 14. Q10: I think Wechat public account based mobile learning mode will distract students from studying so that they can't grasp the focus of leaning

\begin{tabular}{lll}
\hline Options & Number & Percentage \\
\hline Strongly disagree & 7 & 14.29 \\
Disagree & 25 & 51.02 \\
Neutral & 11 & 22.45 \\
Agree & 3 & 6.12 \\
Strongly agree & 3 & 6.12 \\
\hline
\end{tabular}

Over half $(51.02 \%)$ of the students disagree with the distraction effect of the Wechat public account based mobile learning mode and the mean of Question 10 is 2.39 which indicates the negative stand of the question.

Question 11 concerns about the additional function of Wechat public account based mobile learning mode. The data from Table 15 shows that $48.98 \%$ of the students believe this mode can improve other abilities while $30.61 \%$ of the students remain neutral and $14.29 \%$ choose disagreement. The mean of this question is 3.39 which means majority of the students choose the neutral position toward this question. The reason why students choose neutral position may be the limitation of the Wechat platform and the design of the course. Wechat public account is a tool for dissemination of information but not for information search and the current Wechat platform makes it hard to give tasks for students to promote their team work.

Table 15. Q11: I think Wechat public account based mobile learning mode can improve other abilities such as team work, information searching, knowledge consolidation, etc.

\begin{tabular}{lll}
\hline Options & Number & Percentage \\
\hline Strongly disagree & 1 & 2.04 \\
Disagree & 7 & 14.29 \\
Neutral & 15 & 30.61 \\
Agree & 24 & 48.98 \\
Strongly agree & 2 & 4.08 \\
\hline
\end{tabular}


Question 12-14 are about the contents of English and American literature teaching. The result of Question 12 is listed in the following Table 16.

Table 16. Q12: I think Wechat public account based mobile learning mode helps in learning about writers' characteristics and style

\begin{tabular}{lll}
\hline Options & Number & Percentage \\
\hline Strongly disagree & 0 & 0 \\
Disagree & 1 & 2.04 \\
Neutral & 7 & 14.29 \\
Agree & 35 & 71.43 \\
Strongly agree & 6 & 12.24 \\
\hline
\end{tabular}

$71.43 \%$ of students choose the option of "agree" and $12.24 \%$ "strongly agree" with the statement of the possibility of Wechat public account based mobile learning mode to help students better understand writers' characteristics and styles. Owing to every week's article from Wechat public account has a special study in writers' writing features and styles, students' positive attitude is reflected in the high mean (3.94) of question 13.

Table 17. Q13: I think Wechat public account based mobile learning mode makes for grasping the theme of literature works

\begin{tabular}{lll}
\hline Options & Number & Percentage \\
\hline Strongly disagree & 1 & 2.04 \\
Disagree & 1 & 2.04 \\
Neutral & 9 & 18.37 \\
Agree & 32 & 65.31 \\
Strongly agree & 6 & 12.24 \\
\hline
\end{tabular}

Question 13 focuses on the theme of literature works. Nearly two thirds $(65.31 \%)$ of the students agree with the statement, which is shown in Table 17. Students who choose the option of strongly agree and the option of neutral account $12.24 \%$ and $18.37 \%$ respectively. The mean of this question is also high which is 3.84 . So it is sure that students are certain about Wechat public account based mobile learning mode in grasping the theme of literature works.

When it comes to the understanding of the literature history, the result remains nearly the same with Question 13. Overall, mean of Question 14 (3.78) shows students' positive attitude. The data in Table 18 indicates $55.1 \%$ of students agree that this mode makes them learn better with literature history. $14.29 \%$ of the students even choose the option of "strongly agree". $24.49 \%$ choose neutral while none choose the option of strongly disagree.

Table 18. Q14: I think Wechat public account based mobile learning mode can help students with their understanding of the literature history

\begin{tabular}{lll}
\hline Options & Number & Percentage \\
\hline Strongly disagree & 0 & 0 \\
Disagree & 3 & 6.12 \\
Neutral & 12 & 24.49 \\
Agree & 27 & 55.1 \\
Strongly agree & 7 & 14.29 \\
\hline
\end{tabular}


Part 4 is quite different from previous part for its design in the options of questions. In part 4 , there are two kinds of questions, namely, multiple choice questions (various answers) and Likert scale questions. Question 15 concerns about the difference between Wechat public account based mobile learning mode and traditional classroom teaching. The result is showed in the following Table 19.

Table 19. Q15: What are the differences between the WeChat public account based mobile learning mode and traditional classroom teaching

\begin{tabular}{lll}
\hline Options & Number & Percentage \\
\hline Different information channel & 43 & 87.76 \\
Different degree of timeliness & 39 & 79.59 \\
Different teaching method & 24 & 48.98 \\
Different interactive mode & 22 & 44.9 \\
Different degree of amusement and attraction & 36 & 73.47 \\
\hline
\end{tabular}

Because students can choose more than one answer in this kind of question, so the highest percentage matters the most among all options. $87.76 \%$ of the students think the difference between those two kinds of learning ways is significant in information channel. Other difference is their degree of timeliness in dissemination of knowledge which accounts for $79.59 \%$. The creative and new form of learning resources in Wechat platform also contribute to difference in degree of amusement and attraction when compared with traditional classroom teaching, so $73.47 \%$ choose the option different degree of amusement and attraction.

Question 16 concerns about the shortcomings of Wechat public account based mobile learning mode. The date in Table 20 shows that $69.39 \%$ of the students believe articles in Wechat platform are not explained in detail. Other drawback of this mode is its inconvenient feedback channel so that $59.18 \%$ of the students choose the option of ineffective feedback channel.

Table 20. Q16: In your opinion, what are the disadvantages of Wechat public account based mobile learning mode compared with that of traditional classroom teaching

\begin{tabular}{lll}
\hline Options & Number & Percentage \\
\hline Wide range of content & 14 & 28.57 \\
Undetailed interpretation & 34 & 69.39 \\
Some repetitive aspects with classroom teaching & 10 & 20.41 \\
Ineffective feedback channel & 29 & 59.18 \\
\hline
\end{tabular}

Question 17 and 18 focus on the relationship between Wechat public account based mobile learning mode and classroom teaching. The data of Question 17 are listed in Table 21.

Table21. Q17: I think Wechat public account based mobile learning mode is not as important as classroom teaching

\begin{tabular}{lll}
\hline Options & Number & Percentage \\
\hline Strongly disagree & 0 & 0 \\
Disagree & 4 & 8.16 \\
Neutral & 10 & 20.41 \\
Agree & 31 & 63.27 \\
Strongly agree & 4 & 8.16 \\
\hline
\end{tabular}

From the above statistics, the percentage of students who choose the option of DISAGREE is the same with the 
students who choose STRONGLY AGREE. Both of two groups take 8.16\%. 63.27\% agrees with the statement in Question 17. The number of students who choose NEUTRAL account $20.41 \%$. The mean of this question is 3.71 which means the positive stand to the statement of Question 17-Wechat mobile learning mode is less important than classroom teaching.

Interestingly, the result of Question 18 (Table 22) corroborates the finding in Question 17. 59.18\% of the students choose the option of STRONGLY DISAGREE when answering Question 18. 22.45\% choose the option of DISAGREE. The mean of question 18 (1.63) states a negative position in answering this question, which means that most of the students do not think Wechat public account based mobile learning mode can substitute classroom teaching.

Table 22. Q18: I think Wechat public account based mobile learning mode can substitute classroom teaching

\begin{tabular}{lll}
\hline Options & Number & Percentage \\
\hline Strongly disagree & 29 & 59.18 \\
Disagree & 11 & 22.45 \\
Neutral & 8 & 16.33 \\
Agree & 0 & 0 \\
Strongly agree & 1 & 2.04 \\
\hline
\end{tabular}

Part 5 starts with students' attitude toward the introduction of Wechat public account based mobile learning mode into university campus. The result is listed in Table 23.

Table 23. Q19: I think Wechat public account based mobile learning mode should be introduced to universities

\begin{tabular}{lll}
\hline Options & Number & Percentage \\
\hline Strongly disagree & 1 & 2.04 \\
Disagree & 2 & 4.08 \\
Neutral & 15 & 30.61 \\
Agree & 26 & 53.06 \\
Strongly agree & 5 & 10.2 \\
\hline
\end{tabular}

As can be seen from the result (Table 23), the option of STRONGLY DISAGREE, DISAGREE, NEUTRAL, AGREE and STRONGLY AGREE account for 2.04\%, 4.08\%, 30.61\%, 53.06\% and 10.2\% respectively. The mean (3.65) ensures a positive attitude toward this statement. Most of the students want the university to adopt this mode.

Question 20 concerns the aspects of improvement of students' abilities. 89.8\% of the students believe it improves their information acquiring ability and $67.35 \%$ think their fast reading abilities are promoted. $22.45 \%$ choose the option of analysis and understanding ability.

Table24. Q20: In your opinion, which ability(abilities) does(do) Wechat public account based mobile learning mode help to improve

\begin{tabular}{lll}
\hline Options & Number & Percentage \\
\hline Analysis and understanding ability & 11 & 22.45 \\
Fast reading ability & 33 & 67.35 \\
Information getting ability & 44 & 89.8 \\
\hline
\end{tabular}

Question 21 focuses on the content design of the Wechat articles. In the following Table 25, there are three options, audio and video, picture, and text story. 
Table 25. Q21: In your opinion, which module of Wechat public account based mobile learning mode is the most helpful for learning

\begin{tabular}{lll}
\hline Options & Number & Percentage \\
\hline Audio, video & 11 & 22.45 \\
Picture & 16 & 32.65 \\
Text story & 36 & 73.47 \\
\hline
\end{tabular}

Nearly three out of four students (73.47\%) think the module of text story in the Wechat articles is the most helpful for their literature information learning. The second important one goes to picture which accounts for $32.65 \%$ while audio and video only takes $22.45 \%$. From the data, we can infer that storytelling text are the most important in Wechat articles because of its eye-catching features and pending contents. The reason why pictures win out audio and video in the Wechat articles would be that pictures are more direct in expressing ideas. Under certain situation, the sound or voice from the audio or video is not allowed to be heard especially in a quiet place such as library etc. Besides, listening or watching takes more time in learning when compared to reading pictures.

Table 26. Q22: What suggestion(s) do you think can improve Wechat public account based mobile learning mode

\begin{tabular}{lll}
\hline Options & Number & Percentage \\
\hline Increasing the knowledge points & 31 & 63.27 \\
Unifying layout design & 17 & 34.69 \\
Providing Chinese and English comparisons & 28 & 57.14 \\
Others & 5 & 10.2 \\
\hline
\end{tabular}

The last question is about the students' expectation and suggestion to current Wechat public account based mobile learning mode. Table 26 tells us that $63.27 \%$ of the students think increasing the knowledge points is the top-one concern of the designer and writer of those Wechat articles. $57.14 \%$ of the students believe providing Chinese and English comparisons is also important for their learning efficiency as certain contents in literature are hard to understand in English. Thus, Chinese translation in such situation is necessary for them. 34.69\% choose the option of unifying layout design. First impression is really important for the short Wechat articles, and without good design, students may not even read those articles so that the effort in this mode will be in vain.

\section{Conclusion and Suggestions}

This paper has used Edgar Dale's Audio-visual Learning Theory and Jean Piaget's Constructionist Learning Theory as the theoretical framework to conduct two control experimental tests and a questionnaire research to investigate the aspects such as students' impression and expectations toward Wechat public account based mobile learning mode as well as its validity, advantages and shortcomings. After investigation and analysis, the survey indicates that: (1) students who use Wechat public account based mobile learning mode behave well in both knowledge learning and exams; (2) students' mobile learning habit is a good foundation for them to accept the new Wechat learning mode; (3) most students hold a positive impression on this Wechat mobile learning mode, so universities and colleges could introduce this mode to their curriculum design; (4) this Wechat mobile learning mode does help students in their literature learning, such as interest arousing, ability improvement, literary contents learning, etc.; (5) Wechat mobile learning is just an extension of the current learning form, and cannot replace the existing, formal school education, and can only be a supplement to existing education; (6) As an important teaching aid, Wechat public account based mobile learning mode benefits teachers in the aspects of information dissemination, interactive mode and updated contents; (7) Improvement of the current Wechat mobile learning mode is possible through students' suggestions. Its performance can be further enhanced from the adjustment of knowledge points, rebuilding of the layout design, providing translations and storytelling narrations and so on.

Owing to the limited time and resources, this study has some drawbacks as well. First of all, the students chosen in this study are junior students which makes the results of the study not applicable to all the university students, 
so future study can be expanded to include students from all four grades in order to increase the credibility of previous studies. Secondly, it is not enough to carry out only two similar tests for different teaching contents for the first half of this semester's teaching content focuses on English literature while the second half is about American literature. Students' performance may change with learning process and more tests both in English literature and American literature teaching are required to reduce the experimental errors in current tests in this paper. The third shortcoming lies in the very nature of Wechat public account based learning mode. This kind of learning depends greatly on students' self-consciousness and willingness to learn, and thus it is hard to ensure that all the students finish the learning task on Wechat platform, which also affects the results of the tests. In the future, if time is permitted, it is possible to redesign the interface of the Wechat public article to set the check point function of every article on the Wechat public account so as to make sure students accomplish their study assignments.

On the whole, in the future, Wechat public account based mobile learning mode should emphasize on practical skills promotion and development and its teaching mode would adapt to each student's performance and habit. With the introduction of "mobile learning" and the improvement of current Wechat platform, more and more universities and colleges will utilize Wechat public account based mobile learning mode and combine their tradition classroom teaching with the mobile learning mode for WeChat mobile learning will efficiently activate students' learning potentials and improve English and American literature teaching innovation.

\section{References}

Barnes, D. (2001). Distance education and it application in continuing education for the poultry industry. The Journal of Applied Poultry Research, 10, 288-292. https://doi.org/10.1093/japr/10.3.288

Buehler, M., Dopp, E., Hughes, K., \& Thompson J. (2001). It takes a library to support distance learners. Internet Reference Services Quarterly, 5, 5-24. https://doi.org/10.1300/J136v05n03_02

Chen, C. H., Yang, J. C., Shen, S., \& Jeng, M. C. (2007). A desktop virtual reality earth motion system in astronomy education. Educational Technology \& Society, 10, 289-304.

Cooper, M. R. (1958). The Two Ends of the Log. Minneapolis: University of Minnesota Press.

Cross, K. P. (1987). Teaching for learning. AAHE Bulletin, 39(8).

Durmus, Y. T. (2016). Effective Learning Environment Characteristics as a requirement of Constructivist Curricula: Teachers' Needs and School Principals' Views. International Journal of Instruction, 9(2).

Edgar, D. (1970). Edgar Dale on Audio-Visual Author(s), Theory into Practice, 9, 101-105. https://doi.org/10.1080/00405847009542261

Golich, V. L., Boyer, M., Franko, P., \& Lamy, S. (2000). The ABCs of case teaching. Washington, DC: Georgetown University.

Harel, I., \& Papert, S. (1991). Constructionism: research reports and essays, 1985-1990. Ablex Publication Corporation.

Harker, E. (2008). Practitioner commentary on: Fride 'n K. The librarian as a teacher: Experiences from a problem-based setting. Health libraries review. Health Information and Libraries Journal, 25, 30-31. https://doi.org/10.1111/j.1471-1842.2008.00801.x

Jiang, et al. (2016). Construction of a Wechat-based Leaning Mode of Mult-terminal Interactive Inquiry and the Empirical Study. Journal of Distance Education, 6, 46-54.

Ken, M. (2013). Edgar Dale's Pyramid of Learning in medical education: A literature review. Medical Teacher, 35, 1584-1593. https://doi.org/10.3109/0142159X.2013.800636

Khan, M., Muhammad, N., Ahmed, M., Saeed, F., \& Khan, S. A. (2012). Impact of activity-based teaching on students' academic achievements in physics at secondary level. Academic Research International, 3, 146-156.

Kirschner, P. A., Sweller, J., \& Clark, R. E. (2006). Why minimal guidance during instruction does not work: an analysis of the failure of constructivist, discovery, problem-based, experiential, and inquiry-based teaching. Educational Psychologist, 41, 75-86. https://doi.org/10.1207/s15326985ep4102_1

Krain, M., \& Lantis, J. S. (2006). Building knowledge? Evaluating the effectiveness of the global problems $\begin{array}{lllll}\text { summit simulation. International Studies } & \text { Perspectives, } & 7, & \text { 395-407. }\end{array}$ https://doi.org/10.1111/j.1528-3585.2006.00261.x 
Laffey, J., Tupper, T., Musser, D., \& Wedman, J. (1998). A computer-mediated support system for project-based learning. Educational Technology Research and Development, 46, 73-86. https://doi.org/10.1007/BF02299830

Li, Z. Z., Cheng, Y. B., \& Liu, C. C. (2013). A constructionism framework for designing game-like learning systems: Its effect on different learners. British Journal of Educational Technology, 44, 208-224. https://doi.org/10.1111/j.1467-8535.2012.01305.x

Liu \& Jiang. (2015). A Design and Teaching Practice of College English Teaching Based on Wechat Platform. Foreign Language and Literature, 2, 138-143.

Mayer, R. (2004). Should there be a three-strikes rule against pure discovery learning? The case for guided methods of instruction. American Psychologist, 59, 14-19. https://doi.org/10.1037/0003-066X.59.1.14

Martinez, M., \& Jagannathan, S. (2010). Social networking, adult learning success and Moodle. In T. T. Kidd, \& J. Keengwe (Eds.). Adult learning in the digital age. Hershey: Information Science References, 68-80. https://doi.org/10.4018/978-1-60566-828-4.ch007

Meng. (2017). On the Recessive Classroom Construction of Foreign Literature in Colleges and Universities Based on WeChat Platform. China Education of Light Industry, 6, 64-67.

Miao. (2016). English Mobile Learning Strategies in Universities and Colleges Based on WeChat. China Educational Technology, 3, 136-140.

Northwood, M. D., Northwood, D. O., \& Northwood, M. G. (2003). Problem-based learning (PBL): From the health sciences to engineering to value-added in the workplace. Global J Eng Educ, 7, 157-164.

Pinto, L. E., Spares, S., \& Drisco, L. (2012). 95 strategies for remodeling instruction. Thousand Oaks, CA: Sage.

Schmidt, H. G., Loyens, S. M. M., Gog, V. T., \& Paas, F. (2007). Problem-Based Learning is Compatible with Human Cognitive Architecture: Commentary on Kirschner, Sweller, and Clark. Educational Psychologist, 42, 91-97. https://doi.org/10.1080/00461520701263350

Shan et al. (2015). Mobile Micro-Learning Research Based on the WeChat Public Platform: A Case Study of a "Data Structure" Course. Open Education Research, 1, 97-104.

Taber, K. S. (2011). Constructivism as educational theory: Contingency in learning, and optimally guided instruction. In J. Hassaskhah (Ed.), Educational Theory, 39-61.

Thirteen Ed Online (2004). Constructivism as a paradigm for teaching and learning. $\mathrm{http}: / / \mathrm{www}$.thirteen.org/edonline/concept2class/constructivism/index.html.

Tian \& Wei. (2014). Design and Implementation of Ubiquitous Mobile Learning Environment under Hybrid Cloud-Arabic Course Learning Based on Wechat Public Platform. Open Education Research, 6, 103-110.

Wang et al. (2016). The Design of Learning Resources of WeChat Public Platform Supported by New Blended Learning Model. Modern Distance Education Research, 5, 105-112.

Winkler, T., Kritzenberger, H., \& Herczeg, M. (2002). Collaborative and Constructive Learning of Elementary School Children in Experiental Learning Spaces along the Virtuality Continuum. Mensch \& Computer, 56, 115-124.

Wood \& Middleton, (1975). A study of assisted problem solving. British Journal of Psychology, 66, 181-191. https://doi.org/10.1111/j.2044-8295.1975.tb01454.x

Wood, E. (2004). Problem-based learning: Exploiting knowledge of how people learn to promote effective learning. Biosci Educ Available from http://journals.heacademy.ac.uk/doi/abs/10.3108/beej.2004.03000006 (Accessed 22/09/2012).

Woods, D. R. (2006). Preparing for PBL (3rd ed). Hamilton, ON, Canada: McMaster University.

$\mathrm{Xu}$ et al. (2015). Towards a Blended Learning Model Based on WeChat Media Platform. Distance Education in China, 4, 36-42.

Ye. (2017). Foreign Literature Research Learning Based on the Internet-Excellent Course Foreign Literature at Sichuan University. China Educational Technology, 3, 115-120.

Yeh, M. K., Hsieh, H. C., Chang, S. H., Chen, R., \& Tsai, H. Y. (2011). Problem-based learning achievement of K-12 students participating in a nanotechnology hands-on works exhibition in Taiwan. International Journal for Cross-Disciplinary Subjects in Education, 2, 480-486. 
https://doi.org/10.20533/ijcdse.2042.6364.2011.0066

\section{Appendix}

\section{Questionnaire}

\section{Part 1: Basic information}

1. What is your gender?

1) Male

2) Female

2. Have you ever used mobile learning resources on Wechat platform?

1) Yes

2) No

3. How many hours do you spend on mobile learning every day?

1) Less than 1 hour

2) 1 2 hours

3) More than 2 hours

\section{Part 2: Impression of Wechat public account based mobile learning mode}

4. I know Wechat public account based mobile learning mode.

1) Strongly disagree

2) Disagree

3) Neutral

4) Agree

5) Strongly agree

5. I like Wechat public account based mobile learning mode.

1) Strongly disagree

2) Disagree

3) Neutral

4) Agree

5) Strongly agree

6. I can adapt to Wechat public account based mobile learning mode.

1) Strongly disagree

2) Disagree

3) Neutral

4) Agree

5) Strongly agree 


\section{Part 3: Validity of Wechat public account based mobile learning mode}

7. The Wechat public account based mobile learning mode arouses my interest in learning English and American literature.
1) Strongly disagree
2) Disagree
3) Neutral
4) Agree
5) Strongly agree

8. I think Wechat public account based mobile learning mode can improve the self-learning ability of English and American literature.
1) Strongly disagree
2) Disagree
3) Neutral
4) Agree
5) Strongly agree

9. I think Wechat public account based mobile learning mode can help teachers better teach English and American literature courses.
1) Strongly disagree
2) Disagree
3) Neutral
4) Agree
5) Strongly agree

10. I think Wechat public account based mobile learning mode will distract students from studying so that they can't grasp the focus of leaning.
1) Strongly disagree
2) Disagree
3) Neutral
4) Agree
5) Strongly agree

11. I think Wechat public account based mobile learning mode can improve other abilities such as team work, information searching, knowledge consolidation, etc.
1) Strongly disagree
2) Disagree
3) Neutral
4) Agree
5) Strongly agree

12. I think Wechat public account based mobile learning mode helps in learning about writers' characteristics and style.

1) Strongly disagree 
2) Disagree

3) Neutral

4) Agree

5) Strongly agree

13. I think Wechat public account based mobile learning mode makes for grasping the theme of literature works.
1) Strongly disagree
2) Disagree
3) Neutral
4) Agree
5) Strongly agree

14. I think Wechat public account based mobile learning mode can help students with their understanding of the literature history.
1) Strongly disagree
2) Disagree
3) Neutral
4) Agree
5) Strongly agree

Part 4: Comparison between Wechat public account based mobile learning mode and teacher classroom teaching

15. What are the differences between the WeChat public account based mobile learning mode and traditional classroom teaching? [multiple choice question]
1) Different information channel
2) Different degree of timeliness
3) Different teaching method
4) Different interactive mode
5) Different degree of amusement and attraction

16. In your opinion, what are the disadvantages of Wechat public account based mobile learning mode compared with that of traditional classroom teaching? [multiple choice question]
1) Wide range of content
2) Undetailed interpretation
3) Some repetitive aspects with classroom teaching
4) Ineffective feedback channel

17. I think Wechat public account based mobile learning mode is not as important as classroom teaching.

1) Strongly disagree

2) Disagree

3) Neutral

4) Agree 
5) Strongly agree

18. I think Wechat public account based mobile learning mode can substitute classroom teaching.

1) Strongly disagree

2) Disagree

3) Neutral

4) Agree

5) Strongly agree

\section{Part 5: Expectations of Wechat public account based mobile learning mode}

19. I think Wechat public account based mobile learning mode should be introduced to universities.

1) Strongly disagree

2) Disagree

3) Neutral

4) Agree

5) Strongly agree

20. In your opinion, which ability(abilities) does(do) Wechat public account based mobile learning mode help to improve. [multiple choice questions]

1) Analysis and understanding ability

2) Fast reading ability

3) Information getting ability

21. In your opinion, which module of Wechat public account based mobile learning mode is the most helpful for learning. [multiple choice question]

1) Audio, video

2) Picture

3) Text story

22. What suggestion(s) do you think can improve Wechat public account based mobile learning mode? [multiple choice question]

1) Increasing the knowledge points

2) Unifying layout design

3) Providing Chinese and English comparisons

4) Others

\section{Copyrights}

Copyright for this article is retained by the author(s), with first publication rights granted to the journal.

This is an open-access article distributed under the terms and conditions of the Creative Commons Attribution license (http://creativecommons.org/licenses/by/4.0/). 